\title{
The study of maternal and perinatal outcome in prolonged pregnancy
}

\section{Shivani Singh*, Hem Prabha Gupta, Urvashi Verma, Gunjan Yadav}

Department of Obstetrics and Gynecology, Era’s Lucknow Medical College and Hospital, Lucknow, Uttar Pradesh, India

Received: 05 January 2017

Accepted: 04 February 2017

*Correspondence:

Dr. Shivani Singh,

E-mail: bundela.shivani@gmail.com

Copyright: (c) the author(s), publisher and licensee Medip Academy. This is an open-access article distributed under the terms of the Creative Commons Attribution Non-Commercial License, which permits unrestricted non-commercial use, distribution, and reproduction in any medium, provided the original work is properly cited.

\begin{abstract}
Background: Prolonged pregnancy or post-dated pregnancy is that pregnancy which has exceeded duration considered to be upper limit of normal pregnancy that is above 40 completed weeks or 280 days from the first day of last menstrual period. The objective was to evaluate the maternal and perinatal outcome of post-dated pregnancy.

Methods: A prospective case control study was conducted on antenatal women for 18 months period from May 2014October 2015 admitted to the Obstetrics and Gynecology Department, Era's Lucknow Medical College and Hospital, Lucknow, Uttar Pradesh, India. The study group was comprised of antenatal women having pregnancy beyond 40 weeks, and the control group was represented with antenatal women between 37-40 weeks admitted for delivery during this period.

Results: The prevalence of post-dated pregnancy was found to be $17.6 \%$ and of post-term was 5.69\%. Among postdated subjects LSCS rate was $56.50 \%$ and in term (37-40 weeks) patient it was $34.18 \%$. The NICU admission for birth asphyxia was $6.09 \%$ among term (37-40 weeks) patients and $17.6 \%$ in post-dated pregnancies.

Conclusions: Any pregnancy that crosses expected date of delivery, Foetal well-being must be assessed and induction of labour should be considered to decrease the risk of perinatal morbidity and mortality.
\end{abstract}

Keywords: LSCS, Perinatal, Post-dated pregnancy

\section{INTRODUCTION}

Prolonged pregnancy or post-dated pregnancy is that pregnancy which has exceeded duration considered to be upper limit of normal pregnancy that is above 40 completed weeks or 280 days from the first day of last menstrual period. The post term pregnancy is defined as pregnancy that has extended to or beyond 42 weeks of gestation (ACOG 2004). ${ }^{1}$ The incidence of post term pregnancy varied from 3-12\%., ${ }^{1,2}$ Post term pregnancies are associated with both foetal and maternal complications. ${ }^{3}$ These pregnancies are at increased risk of umbilical cord compression from oligohydroamnios, Nonreassuring foetal antepartum or intrapartum assessment, intrauterine passage of meconium and short term neonatal complications (such as hypoglycaemia seizures and respiratory in problems). The rate of complications rises as pregnancies advance their due date, even before reaching 42 weeks of gestation. ${ }^{4-6}$ The recent data have shown that a major cases of perinatal asphyxia occurs between 40 and 42 weeks of gestation. ${ }^{7}$

\section{METHODS}

This was a prospective case control study of 18 month period from May 2014 to October 2015 conducted on antenatal women admitted to Obstetrics and Gynaecology department of Era's Lucknow Medical College and Hospital, Lucknow, Uttar Pradesh, India. The study group was comprised of women having pregnancy beyond 40 weeks without any other associated problem and the outcome was noted. The control group was 
represented by the women who were admitted for delivery between 37 and 40 weeks of gestation. Cases with multiple pregnancies, malpresentation, APH, medical conditions like heart disease and hypertension were excluded from the study.

\section{RESULTS}

Total number of deliveries during the study period was 1092 out of which 193 were post-dated and 623 were term (37-40 weeks) rest of the antenatal women were excluded from the study due to associated complications like malpresentation, APH etc. The prevalence of deliveries after the 40 weeks of pregnancy was $17.6 \%$.Comparision was made with 623 term (37-40 weeks) pregnancies. Out of 193 post-dated pregnancies $138(71.50 \%)$ were between $40-41$ weeks, $44(22.79 \%)$ between 41-42 weeks and $11(5.69 \%)$ were $>42$ weeks. The prevalence of post-term pregnancy was $5.69 \%$. In present study the prevalence of post-dated pregnancy was $17.6 \%$ and of post term pregnancy was $5.69 \%$. Post=dated pregnancy was more prevalent in 20-29 years of age group $(83.41 \%)$ (Table 1$)$.
Table 1: Age.

\begin{tabular}{|c|c|c|c|c|}
\hline $\begin{array}{l}\text { Age } \\
\text { (years) }\end{array}$ & \multicolumn{2}{|c|}{$\begin{array}{l}\text { Term }(n=623) \\
(37-40) \text { weeks }\end{array}$} & \multicolumn{2}{|c|}{$\begin{array}{l}\text { Post-dated } \\
(n=193) \\
(>40) \text { weeks }\end{array}$} \\
\hline 20-30 & 515 & $82.2 \%$ & 161 & $83.4 \%$ \\
\hline$>30$ & 108 & $17.33 \%$ & 32 & $16.5 \%$ \\
\hline
\end{tabular}

Table 2: Parity.

\begin{tabular}{|c|c|c|c|c|}
\hline & \multicolumn{2}{|c|}{$\begin{array}{l}\text { Term }(n=623) \\
(37-40) \text { weeks }\end{array}$} & \multicolumn{2}{|c|}{$\begin{array}{l}\text { Postdated }(n=193) \\
(>40) \text { weeks }\end{array}$} \\
\hline Primi & 205 & $32.9 \%$ & 94 & $48.7 \%$ \\
\hline Multi & 418 & $67.03 \%$ & 99 & $51.2 \%$ \\
\hline
\end{tabular}

$\chi^{2}=15.84, \mathrm{p}<0.001$.

Women who delivered at term (37-40 weeks) were mostly multigravida $418(67.09 \%)$ and the incidence of post-dated deliveries was almost equal in primi and multigravida (Table 2).

Table 3: Type of delivery.

\begin{tabular}{|lllll|}
\hline Age of gestation & Total patient & Normal delivery & LSCS & Instrumental delivery \\
\hline Term (37-40 weeks) & 623 & $406(65.16 \%)$ & $213(34.18 \%)$ & $4(0.64 \%)$ \\
\hline Post-dated & & & & \\
\hline $40-41$ weeks & 138 & $80(57.9 \%)$ & $56(40.57 \%)$ & $2(1.44 \%)$ \\
\hline $41-42$ weeks & 44 & $19(43.18 \%)$ & $22(50 \%)$ & $3(6.81 \%)$ \\
\hline$>42$ & 11 & $5(45.45 \%)$ & $6(54.50 \%)$ & 0 \\
\hline
\end{tabular}

$\chi^{2}=23.5, \mathrm{p}=0.001$.

Table 4: Presence of meconium during labour.

\begin{tabular}{|lll|}
\hline $\begin{array}{l}\text { Gestation } \\
\text { (weeks) }\end{array}$ & Total & Presence of meconium \\
\hline $37-40$ & 623 & $64(10.27 \%)$ \\
\hline $40-41$ & 138 & $25(18.11 \%)$ \\
\hline $41-42$ & 44 & $14(31.8 \%)$ \\
\hline$>42$ & 11 & $5(45.4 \%)$ \\
\hline
\end{tabular}

$\chi^{2}=30.8, \mathrm{p}<0.001$.

Table 5: Comparison of birth weight.

\begin{tabular}{|lll|}
\hline Weight (kg) & $\begin{array}{l}\text { Term }(37-40) \\
\text { weeks }\end{array}$ & $\begin{array}{l}\text { Post-dated } \\
(>40) \text { weeks }\end{array}$ \\
\hline$<2 \mathrm{Kg}$ & $23(3.69 \%)$ & 0 \\
\hline $2-2.5 \mathrm{Kg}$ & $175(28.08 \%)$ & $23(13.98 \%)$ \\
\hline $2.5 \mathrm{Kg}$ & $257(41.25 \%)$ & $80(41.45 \%)$ \\
\hline$>3-3.5 \mathrm{Kg}$ & $168(26.50 \%)$ & $90(46.63 \%)$ \\
\hline
\end{tabular}

$\chi^{2}=41.0, \mathrm{p}<0.001$

Among post-dated subjects caesarean section rate was $40.57 \%$ in $40-41$ week pregnancy, $50 \%$ in $41-42$ week pregnancy and $54.50 \%$ in $>42$ weeks pregnancy. In the
623 control patients, $406(65.16 \%)$ had normal delivery, $213(34.18 \%)$ underwent LSCS and $4(0.64 \%)$ had instrumental delivery (Table 3 ). In the control group intrapartum complication was presence of meconium in $64(10.27 \%)$ as compare to the $44(22.7 \%)$ patient in post-dated group. Among post-dated group the meconium was found in $18.11 \%$ cases at (40-41) weeks, $31.8 \%$ cases at (41-42) weeks and in $45.4 \%$ cases at $>42$ weeks (Table 4). The average birth weight in term group was $2.75 \mathrm{~kg}$ and $3.25 \mathrm{~kg}$ in post-dated group (Table 5). Cases were broadly divided in to four groups according to the apgar score at 5 minute after birth (Table 5). Foetal outcome with APGAR score $>7$ in $95.02 \%$ cases in term group (37-40 weeks) in $94.20 \%$ at $40-41$ weeks, in $86.36 \%$ at $41-42$ weeks and $81.81 \%$ at $>42$ weeks (Table $6)$.

The NICU admission for birth asphyxia was 38 (6.09\%) out of 623 control subjects and in post-dated pregnancies it was $34(17.61 \%)$ in 193 subjects (Table 7). There were two neonatal deaths in post-dated group. Neonatal morbidity in the form of HIE and meconium aspiration were $17(8.80 \%)$ in post-dated group, while in the control group $23(3.69 \%)$ and $15(2.40 \%)$ respectively. 
Table 6: Apgar score at 5 minutes.

\begin{tabular}{|cllll|}
\hline \multirow{2}{*}{ A pgar score } & Term $(\mathbf{3 7 - 4 0})$ weeks & \multicolumn{4}{l|}{ Postdated $(>\mathbf{4 0})$ weeks } & $\mathbf{4 1 - 4 2}$ weeks & (42 weeks \\
\hline $1-4$ & $14(2.24 \%)$ & $4(2.17 \%)$ & $3(4.54 \%)$ & $1(9.09 \%)$ \\
\hline $5-7$ & $17(2.72 \%)$ & $2(1.4 \%)$ & $3(6.81 \%)$ & $1(9.09 \%)$ \\
\hline$>7$ & $592(95.02 \%)$ & $130(94.20 \%)$ & $38(86.36 \%)$ & $9(81.81 \%)$ \\
\hline
\end{tabular}

$\chi^{2}=18.6, p=0.029$.

Table 7: NICU admission.

\begin{tabular}{|lllll|}
\hline Gestational age in weeks & Number of antenatal women & Meconium aspiration & HIIE & Total \\
\hline $37-40$ weeks & 623 & $15(2.40 \%)$ & $23(3.69 \%)$ & $38(6.09)$ \\
\hline $40-41$ weeks & 138 & $6(4.34 \%)$ & $5(3.62 \%)$ & $11(7.97 \%$ \\
\hline $41-42$ weeks & 44 & $7(15.9 \%)$ & $7(15.9 \%)$ & $14(31.8 \%)$ \\
\hline$>42$ weeks & 11 & $4(36.3 \%)$ & $5(45.4 \%)$ & $9(81.8 \%)$ \\
\hline
\end{tabular}

$\chi^{2}=109, \mathrm{p}<0.001$.

\section{DISCUSSION}

Prolonged pregnancy has always been regarded as a high risk condition as it is associated with increase perinatal morbidity and mortality, this risk increases in pregnancies that last two or more weeks after the expected date of delivery. In our study the prevalence of post-dated pregnancy was $17.6 \%$ and of post term pregnancy was- $5.69 \%$. Post-dated pregnancy was more prevalent in 20-29 years of age group (83.41\%). In our country most of the women by the age of 18 years become mother of at least one child that may be the reason of higher incidence in lower age group and in multigravida. This study had shown prevalence of prolonged pregnancy $51.29 \%$ in multi and $48.70 \%$ in primi.

In present study $71.50 \%$ women presented at $40-41$ weeks, $22.79 \%$ at $41-42$ weeks and $5.69 \%$ at $>42$ weeks of pregnancy. This might be due to lack of education, ignorance and unawareness about the complication of post maturity, which could be overcome by proper antenatal care and health education. The exact etiology of prolong pregnancy is not known. Primiparity and prior post-term pregnancy are the most common identifiable risk factors for prolongation of pregnancy. Rarer causes include placental sulfatase deficiency, foetal adrenal insufficiency and foetal anencephaly. The rate of caesarean section was significantly higher (55.95\%) among post-dated pregnancy in comparison to term group $(34.18 \%)$, and this may be due to presence of meconium, failed induction and placental maturation leading to foetal jeopardy during labour. A study from Scotland published in 2010 demonstrate increase risk of still birth as pregnancy advances especially after 39 weeks of gestation. $^{8}$ Aspiration of meconium during intrauterine life may result in meconium aspiration syndrome, is a leading cause of perinatal death as reported by Kistka et al. ${ }^{9}$ The rate of meconium aspiration and neonatal academia both increases as term pregnancies progress beyond 38 weeks by Bruckner et al. ${ }^{10}$ Mannino F et al also observed in their study that the still birth rate is lowest at 40 weeks and gradually increases as pregnancy advanced. ${ }^{11}$

\section{CONCLUSION}

As 42 weeks of gestation does not represent a thresh hold below which risk is uniformly distributed, inducing labour at 41 weeks of gestation in an accurately dated, low risk pregnancy may decrease the perinatal mortality. Any pregnancy that goes beyond 41 weeks of confirmed gestational age foetal well-being must be assessed and proper management should be done to reduce the rate of perinatal morbidity and mortality. Antepartum foetal surveillance is suggested in pregnancies past 40 weeks when delivery is not performed.

Funding: No funding sources

Conflict of interest: None declared

Ethical approval: The study was approved by the Institutional Ethics Committee

\section{REFERENCES}

1. ACOG Practice Bulletin. Clinical management guidelines for obstetricians-gynecologists. Number 55, September 2004 (replaces practice pattern number 6, October 1997). Management of Postterm Pregnancy. Obstet Gynecol. 2004;104(3):639-46.

2. Norwitz ER, Snegovskikh VV, Caughey AB. Prolonged pregnancy: when should we intervene? Clin Obstet Gynecol. 2007;50(2):547-57

3. Doherty L, Norwitz ER; Prolonged pregnancy: when should we intervene? Curr Opin Obstet Gynecol. 2008;20(6):519-27. 
4. Caughy AB, Musci TJ. Complications of term pregnancies beyond 37 weeks of gestation. Obstet Gynacol. 2004;103:57-62.

5. Caughy AB Washington AE, Laros RK Jr. Neonatal complications of term pregnancy rates by gestational age increase in a continous, not threashold, fashion. Am J Obstet Gynacol. 2005;192:185-90.

6. Nicholson JM, Keller LC, Kellar GM. The impact of the interaction between increasing gestational age and obstetric risk on birth outcomes: evidence of a varying optimal time of delivery. $\mathrm{J}$ Perinatol. 2006;26:392-402.

7. Bochner CJ, Williams III J, Castro L Medarias A, Hobel CJ, Wade M. The efficacy of starting postterm antenatal testing at 41 weeks as compared with 42 weeks of gestational age. Am J Obstet Gynecol. 1988;159:550-4.
8. Sutan R, Campbell D, Prescott GJ. The risk factors for unexplained antepartum stillbirths in Scotland, 1994 to 2003. J Perinatol. 2010;30:311-8.

9. Kistka ZA, Palomar L, Baslaugh SE, Debaun MR, Defranco EA, Muglia LJ. Risk of post term delivery after post term delivery. Am J Obstet Gynecol. 2007; 196: 241-6.

10. Bruckner TA, Cheng YW, Caughey AB. Increased neonatal mortality among post-term births in California. Am J Obstet Gynecol. 2008;199:421.

11. Mannino F. Neonatal complications of postterm gestation. J Reprod Med. 1988;33:271-6.

Cite this article as: Singh S, Gupta HP, Verma U, Yadav G. The study of maternal and perinatal outcome in prolonged pregnancy. Int J Reprod Contracept Obstet Gynecol 2017;6:1067-70. 